\title{
PKM Melalui Pelatihan Pembuatan Bak Cuci Tangan untuk Pencegahan Penyebaran Covid-19 di Kota Makassar
}

\author{
Nurlita Pertiwi ${ }^{1}$, Nurul Muhlisa $\mathrm{Abdal}^{2}$ \\ ${ }^{1,2}$ Fakultas Teknik, Universitas Negeri Makassar
}

\begin{abstract}
These Community Partnership Program (PKM) partners are administrators of the Muhajirin Mosque and the Gowa Care Community. The problem faced is the spread of the Covid-19 virus which is increasingly widespread so that efforts need to be made to reduce the level of virus spread. The PRA method is carried out to generate a sense of belonging (sense of belonging) to partners for the products to be developed, and a sense of responsibility (sense of responsibility) of partners towards the products and the environment around them. The main method adopted in this Community Partnership Program (PKM) activity is lectures and hands-on practice. The results achieved were increased public knowledge about the importance of tackling the spread of Covid-19 and increased skills of participants in making hand sinks placed in traditional markets.
\end{abstract}

Keywords: Hand Washing Tub, Covid-19

\section{PENDAHULUAN}

Makassar sebagai kota dengan jumlah penduduk sebanyak 1.526. 677 jiwa (Data BPS Kota Makassar, 2019) memiliki resiko yang besar terhadap pandemi Covid-19. Data pada bulan Maret 2020, bahwa jumlah penderita yang positif Covid-19 sebanyak 33 orang. Selanjutnya pada akhir bulan April 2020 jumlah penderita bertambah hingga 453 orang. Kondisi ini, sangat menghawatirkan bagi masyarakat. Olehnya perlu dilakukan tindakan pencegahan penyebaran penyakit secara menyeluruh.

COVID-19 adalah penyakit menular yang disebabkan oleh jenis coronavirus yang baru ditemukan. COVID-19 ini sekarang menjadi sebuah pandemi yang terjadi di banyak negara di seluruh dunia (Yuliana, 2020). Orang dapat tertular COVID-19 dari orang lain yang terinfeksi virus ini. COVID-19 dapat menyebar terutama dari orang ke orang melalui percikan-percikan dari hidung atau mulut yang keluar saat orang yang terinfeksi COVID-19 batuk, bersin atau berbicara.

Badan Kesehatan Dunia atau WHO serta Kementerian Kesehatan Republik Indonesia No. 3 Tahun 2014 mengeluarkan imbauan mengenai hal yang harus dilakukan dalam mencegah corona jenis baru ini. Upaya yang bisa dilakukan adalah melakukan berbagai upaya pencegahan, salah satunya adalah mencuci tangan menggunakan sabun atau yang sering kita dengar dengan istilah CTPS (Cuci Tangan Pakai Sabun).

Tujuan mencuci tangan adalah untuk menghilangkan mikroorganisme yang bersifat sementara yang mungkin dapat ditularkan ke oranag lain (Berman et al, 2009). Setiap orang berpotensi membawa mikroorganisme sehingga kebiasaan cuci tangan harus dilakukan oleh setiap orang. Pencegahan penyebaran covid ditempat umum menjadi penting karena setiap orang memiliki potensi untuk menularkan mikroorganisme tersebut (Rikayanti, 2014).

Cuci Tangan Pakai Sabun (CTPS) merupakan perilaku sehat yang telah terbukti secara ilmiah dapat mencegah penyebaran penyakit. Tangan yang terkontaminasi dan tidak langsung dicuci dengan sabun dapat memindahkan bakteri, virus, dan parasit pada orang lain yang tidak sadar bahwa dirinya sedang ditularkan. Tangan tersebut selanjutnya menjadi perantara dalam penularan penyakit. Mencuci tangan dengan air saja lebih umum dilakukan, tetapi hal ini terbukti tidak efektif dalam menjaga kesehatan dibandingkan dengan CTPS. Menggunakan sabun dalam mencuci tangan sebenarnya menyebabkan orang harus 
mengalokasikan waktunya lebih banyak saat mencuci tangan, tetapi penggunaan sabun menjadi efektif karena lemak dan kotoran yang menempel akan terlepas saat tangan digosok dan bergesek dalam upaya melepasnya. Di dalam lemak dan kotoran yang menempel inilah kuman penyakit hidup (DepKes RI, 2009)

Kampanye pentingnya cuci tangan pakai sabun memerlukan sarana cuci tangan. Sarana tersebut berupa kran air, bak cuci tangan dan sabun. Ketersediaan bak cuci tangan di tempat umum menjadi hal yang urgent dalam pencegahan penyebaran virus Covid-19. Hasil observasi awal pada beberapa pasar tradisional di Kota Makassar menunjukkan belum ditemukannya fasilitas bak cuci tangan yang memberi kemudahan bagi pengunjung untuk membiasakan diri untuk cuci tangan (observasi bulan Maret dan April 2020). Berdasarkan uraian di atas, maka program pengabdian masyarakat ini melakukan pelatihan bagi masyarakat. Target dari kegiatan ini adalah adanya peningkatan pengetahuan masyarakat tentang teknik pembuatan bak cuci tangan serta pemasangannya.

\section{PELAKSANAAN DAN METODE}

Berdasarkan analisis situasi, permasalahan, dan target yang ingin dicapai, maka metode pelaksanaan kegiatan pengabdian masyarakat ini terbagi atas dua tahap yaitu metode pendampingan (mentoring) dan metode partisipatory rural approach (PRA). Metode pendampingan bertujuan untuk memberikan pengenalan pada masyarakat tentang manfaat bak cuci tangan serta Teknik pembuatannya. sedangkan Metode PRA dilakukan untuk mengembangkan sikap dan keterampilan peserta dalam pembuatan bak cuci tangan. Selain itu peserta diharapkan dapat mengampanyekan kebiasaan mencuci tangan yang benar sebagai Langkah pencegahan penyebaran virus Covid-19. Metode utama yang ditempuh dalam kegiatan Program Kemitraan Masyarakat (PKM) ini adalah:

1. Pada waktu penyajian materi penyuluhan, metode yang digunakan adalah ceramah dan penyuluhan.
2. Pada saat latihan pembuatan bak cuci tangan digunakan metode demonstrasi dan Latihan

Adapun tahapan dalam kegiatan pengabdian ini adalah :

1. Survei dan Analisis masalah. Survei dan analisis masalah merupakan langkah pertama yang dilaksanan untuk mengetahui permasalahan atau kendala tentang penanganan Covid-19 di beberapa pasar tradisional.

2. Perumusan masalah dan pengembangan solusi berdasarkan hasil analisis masalah dapat disimpulkan bahwa beberapa pasar tradisional di Kota Makassar belum memiliki fasilitas bak cuci tangan di tempat umum. Solusi yang dilaksanakan secara umum merupakan proses pelatihan pembuatan cuci tangan yang mudah diadopsi oleh masyarakat. Bahan baku yang digunakan untuk struktur adalah pipa PVC yang mudah ditemukan di lapangan.

3. Pelaksanaan PKM berupa pemberian pelatihan kepada target dengan metode ceramah, diskusi dan praktik langsung membuat bak cuci tangan.

\section{HASIL DAN PEMBAHASAN}

Pelaksanaan pembuatan bak cuci tangan guna pencegahan Covid-19 dilaksanakan dalang rentang waktu 30 Mei - 4 September 2020. Target dari pelakasanaan kegiatan ini adalah pengurus masjid Muhajirin Kecamatan Panakukkang dan komunitas Peduli Gowa di Sungguminasa Gowa Penyajian pelatihan ini bersifat tematik dan mudah dipahami oleh peserta. Peserta pada Pengurus Masjid sebanyak 10 orang sedang pada Komunitas Peduli Gowa sebanyak 20 orang. Khusus pada pengurus Masjid Muhajirin Kecamatan Panakukkang Kota Makassar, pelaksanaan kegiatan yaitu pada tanggal 5 Juni 2020 sedangkan di Kabupaten Gowa dilaksanakan pada tanggal 4 September 2020.

\section{Tahap 1 : Pembuatan Desain Bak Cuci Tangan}

Desain bak cuci tangan guna mencegah penyebaran Covid-19 menggunakan pipa PVC yang mudah didapat oleh masyarakat. Tinggi bak yaitu $80 \mathrm{~cm}$ sedangkan dimensi penyangga wastafel yaitu 50 x $40 \mathrm{~cm}$. Jenis wastafel yang digunakan yaitu wastafel stainless steel dengan 
beberapa kelebihan yaitu mudah dibersihkan, tahan lama, dan ringan. Dimensi bak cuci tangan ini dapat dilihat pada gambar 1 dan 2 .

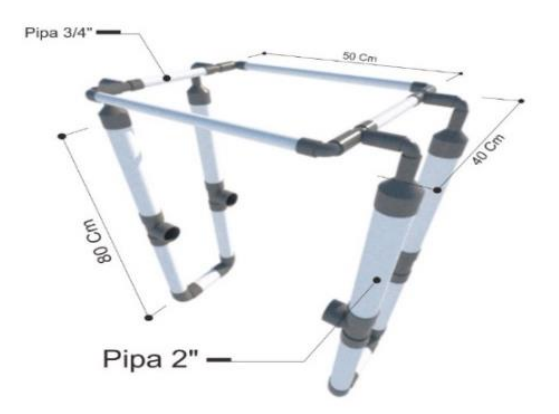

Gambar 1 Desain Dimensi Bak Cuci Tangan

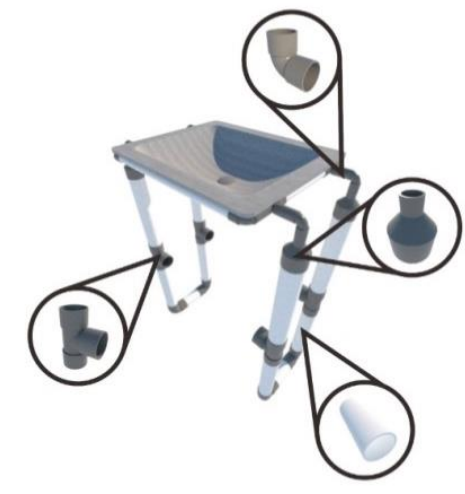

Gambar 2 Desain Bak Cuci Tangan

\section{Tahap 2 : Pengenalan alat dan bahan}

Pada tahap pengenalan alat dan bahan menggunakan metode ceramah dan praktik langsung sehingga efektif meningkatkan keterampilan peserta pelatihan. Pengenalan ini mulai dari bahan yang digunakan pada rangka sampai proses penyatuan tiap bagian bak cuci tangan. Proses pengenalan ini dapat dilihat pada pada gambar 3 dan 4 .

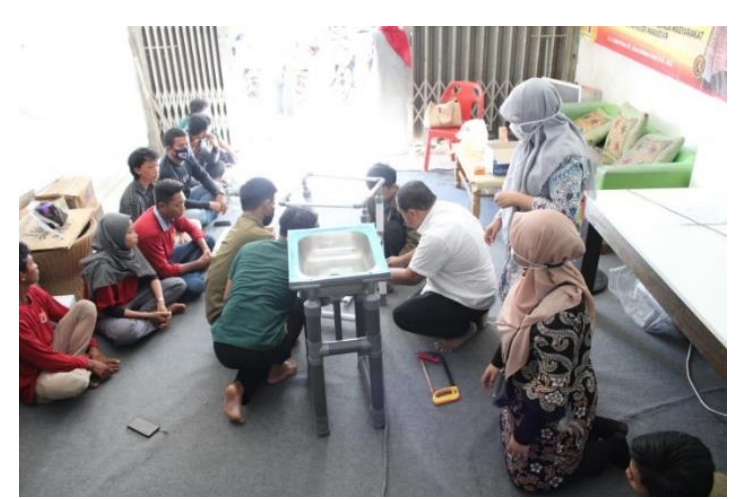

Gambar 3 Pengenalan alat pembuatan bak cuci tangan

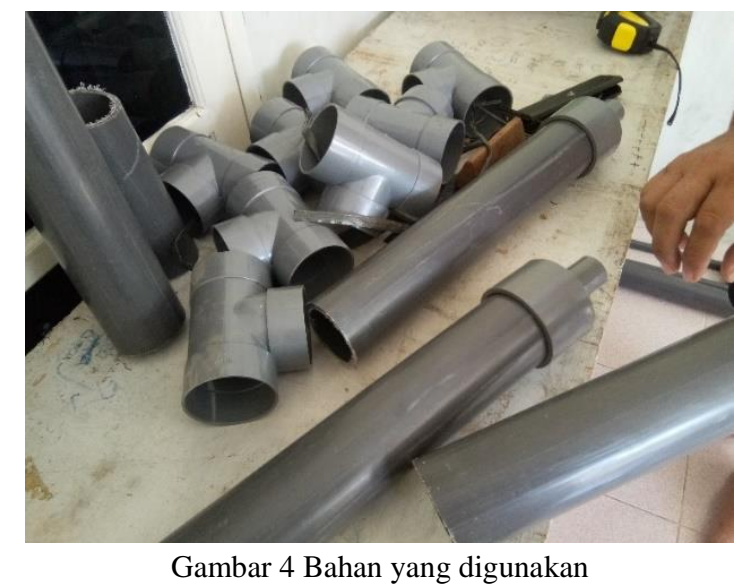

Tahap 3 : Perakitan bak cuci tangan

Proses perakitan mulai dari penyiapan pipa PVC yang disambung menggunakan sambungan $T$ dan sambungan L serta menggunakan lem perekat seperti yang terlihat pada gambar 5. Setelah perakitan rangka maka proses selanjutnya yaitu pemasangan wastafel seperti pada gambar 6 . Proses akhir dalam pembuatan bak ini yaitu pemasangan selang pembuang. Semua bahan yang digunakan merupakan bahan yang mudah didapat oleh masyarakat.

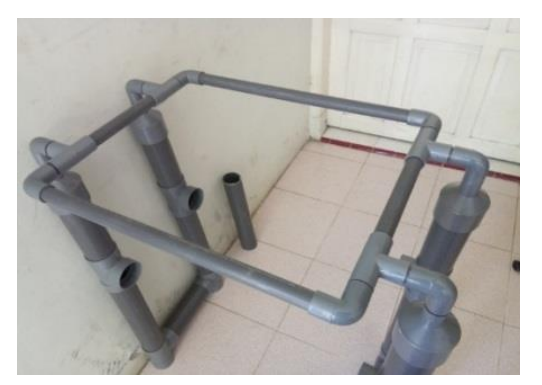

Gambar 5 Perakitan rangka bak cuci tangan

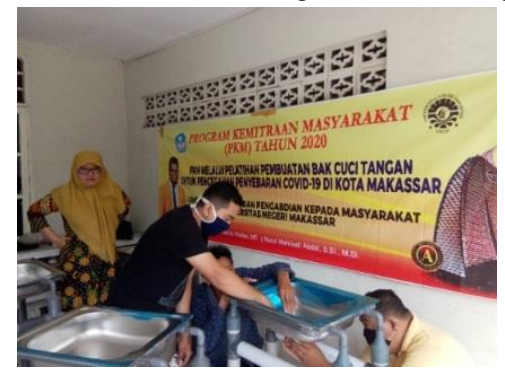

Gambar 6 Pemasangan Wastafel 


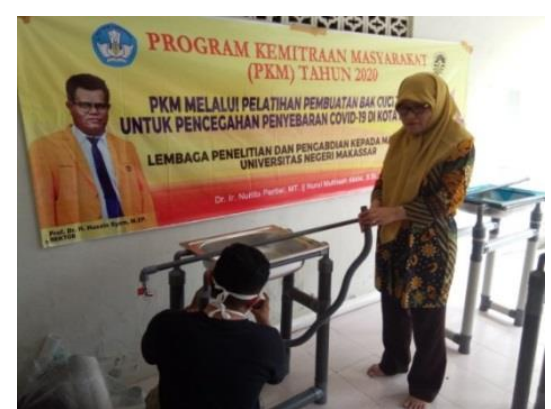

Gambar 7 Pemasangan selang pembuang

Tahap 4 : Pemasangan bak cuci tangan di pasar tradisional

Bak cuci tangan yang telah dirakit harus ditempatkan pada sumber air terdekat serta pada area yang mudah dijangkau oleh masyarakat terutama pada pintu masuk dan pintu keluar pasar tradisional seperti pada gambar 8 .

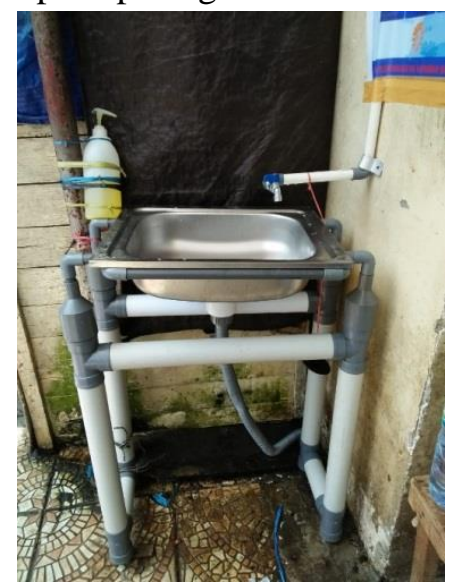

Gambar 8 Pemasangan Bak Cuci Tangan di pasar Tradisional

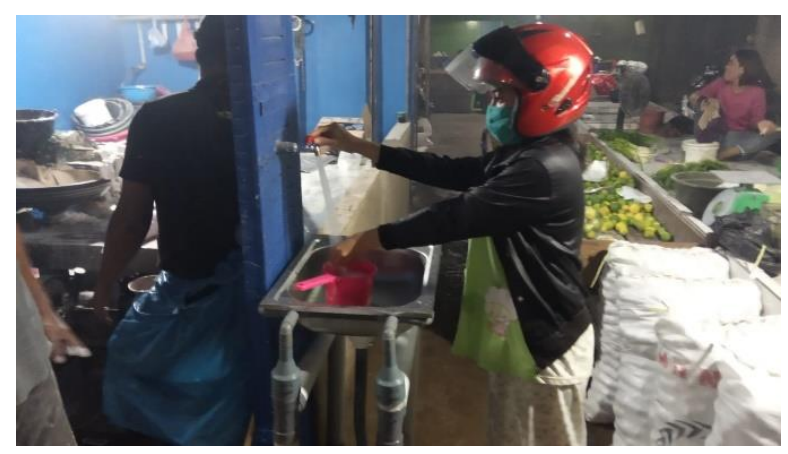

Gambar 9 Pemanfaatan bak cuci tangan di pasar tradisional

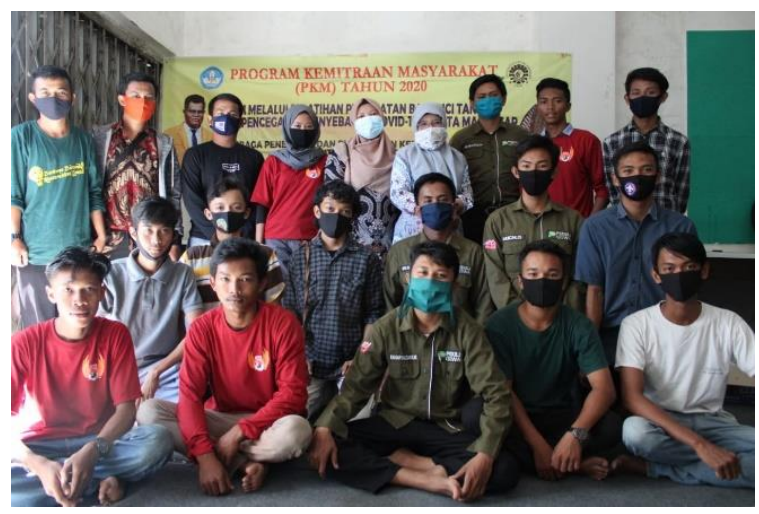

Gambar 9 Acara Penutupan Kegiatan

Evaluasi Peningkatan Pengetahuan dan Keterampilan

Evaluasi peningkatan pengetahuan dan keterampilan pembuatan bak cuci tangan adalah meningkatnya pengetahuan dan keterampilan peserta dalam pemilihan bahan yang digunakan serta pembuatan bak cuci tangan. Aspek ini dapat dikur dari hasil Pre Test dan Post Test yang dapat dilihat pada tabel 1 dan 2.

Tabel 1 Nilai Pengetahuan Peserta Tentang Bak Cuci Tangan

\begin{tabular}{|c|c|c|}
\hline \multirow{2}{*}{ Kategori } & \multicolumn{2}{|c|}{ Nilai } \\
\cline { 2 - 3 } & $\begin{array}{c}\text { Pre } \\
\text { Test }\end{array}$ & $\begin{array}{c}\text { Post } \\
\text { Test }\end{array}$ \\
\hline $\begin{array}{c}\text { Pengetahuan tentang konstruksi } \\
\text { bak cuci tangan }\end{array}$ & 2.45 & 3.8 \\
\hline $\begin{array}{c}\text { Pengetahuan tentang alat dan } \\
\text { bahan yang digunakan pada } \\
\text { konstruksi bak cuci tangan }\end{array}$ & 2.0 & 3.6 \\
\hline Nilai Max & 4.0 & 4.0 \\
\hline
\end{tabular}

Tabel 2 Nilai Keterampilan Peserta dalam Pembutan Bak Cuci

\begin{tabular}{|c|c|c|}
\hline \multicolumn{2}{|c|}{ Tangan } \\
\hline \multirow{2}{*}{ Kategori } & \multicolumn{2}{|c|}{ Nilai } \\
\cline { 2 - 3 } & $\begin{array}{c}\text { Pre } \\
\text { Test }\end{array}$ & $\begin{array}{c}\text { Post } \\
\text { Test }\end{array}$ \\
\hline $\begin{array}{c}\text { Keterampilan dalam perakitan bak } \\
\text { cuci tangan }\end{array}$ & 1.2 & 3.4 \\
\hline $\begin{array}{c}\text { Keterampilan perakitan bak cuci } \\
\text { tangan }\end{array}$ & 2.4 & 3.8 \\
\hline Nilai Max & 4.0 & 4.0 \\
\hline
\end{tabular}

Tabel 1 Menunjukkan adanya peningkatan pengetahuan peserta tentang manfaat bak cuci tangan terhadap penyebaran Covid-19. Pada Pre Test, nampak tingkat pengetahuan peserta yang 
relatif rendah. Sedang hasil Post Test menunjukkan adanya peningkatan pengetahuan peserta.

Tabel 2 Menunjukkan adanya peningkatan yang signifikan terhadap keterampilan peserta dalam pembutan bak cuci tangan ditinjau dari nilai Pre Test 2.4, sedangkan nilai Pos Test meningkat menjadi 3.8.

\section{KESIMPULAN}

Hasil pengabdian ini dapat disimpulkan bahwa program PKM ini telah meningkatkan pengetahuan dan keterampilan masyarakat dalam membuat bak cuci tangan guna mencegah penyebaran Covid-19. Selain meningkatkan keterampilan dan pengetahuan juga sikap menjadi meningkat terutama mengenai pentingnya pencegah penyebaran virus Covid-19. Kegiatan ini mendapatkan respon sangat baik dari masyarakat yang dapat terlihat dengan antusiasme dan kehadiran peserta ketika kegiatan pelatihan berlangsung.

\section{UCAPAN TERIMA KASIH}

Ucapan terima kasih atas berlangsungnya kegiatan program pengabdian masyarakat ini, kami berterimakasih kepada Direktorat Riset dan Pengabdian pada Masyarakat (DRPM). Ristekdikti yang telah mendanai kegiatan ini, pengurus Masjid Muhajjirin serta Komunitas Peduli Gowa yang telah bersedia menjadi mitra dalam pengabdian ini.

\section{DAFTAR PUSTAKA}

Berman, A, dkk. 2009. Kozier \& Erb Buku Ajar Praktik Keperawatan Klinis Edisi 5. Jakarta : EGC.

Depkes RI, 2009. Sistem Kesehatan Nasional. Jakarta.

Fajriyah, N. N. (2015). Pengetahuan mencuci tangan Penunggu Pasien menggunakan lotion antiseptic. In PROSIDINGSEMINAR NASIONAL \& INTERNASIONAL.

Peraturan Menteri Kesehatan Republik Indonesia Nomor 3 Tahun 2014 Tentang Sanitasi Total Berbasis Masyarakat.

Rikayanti, Kadek Herna. 2014. Hubungan Tingkat Pengetahuan dengan Perilaku Mencuci Tangan
Petugas Kesehatan di Rumah Sakit Umum Daerah Badung. Vol. 2. No 1.

Yuliana, Y. (2020). Corona virus diseases (Covid19): Sebuah tinjauan literatur. Wellness And Healthy Magazine, 2(1), 187-192. 